NBER WORKING PAPER SERIES

THE EFFICIENCY OF SPONSOR AND PARTICIPANT PORTFOLIO CHOICES

IN 401(K) PLANS

\author{
Ning Tang \\ Olivia S. Mitchell \\ Gary R. Mottola \\ Stephen Utkus \\ Working Paper 15317 \\ http://www.nber.org/papers/w15317 \\ NATIONAL BUREAU OF ECONOMIC RESEARCH \\ 1050 Massachusetts Avenue \\ Cambridge, MA 02138 \\ September 2009
}

This research is part of the NBER programs on Aging and Labor Economics and was undertaken pursuant to a grant from the US Social Security Administration (SSA) to the Michigan Retirement Research Center (MRRC). This research support is gratefully acknowledged along with that of the Pension Research Council at The Wharton School and Vanguard. The authors also acknowledge Vanguard's efforts in the provision of recordkeeping data under restricted access conditions. The authors thank Raimond Maurer, Theo Nijman, Susan Thorp, and Takeshi Yamaguchi for helpful comments. Opinions expressed herein are those of the authors alone, and not those of The Wharton School, Vanguard, the National Bureau of Economic Research, or any other institution with which the authors may be affiliated.

NBER working papers are circulated for discussion and comment purposes. They have not been peerreviewed or been subject to the review by the NBER Board of Directors that accompanies official NBER publications.

(C) 2009 by Ning Tang, Olivia S. Mitchell, Gary R. Mottola, and Stephen Utkus. All rights reserved. Short sections of text, not to exceed two paragraphs, may be quoted without explicit permission provided that full credit, including (C) notice, is given to the source. 
The Efficiency of Sponsor and Participant Portfolio Choices in 401(k) Plans

Ning Tang, Olivia S. Mitchell, Gary R. Mottola, and Stephen Utkus

NBER Working Paper No. 15317

September 2009

JEL No. G11,G23,J14,J26

\begin{abstract}
$\underline{\text { ABSTRACT }}$
Portfolio performance in 401(k) plans depends on both the investment menu made available by plan sponsors and participants portfolio decisions. We use a unique dataset of nearly 1 million participants in one thousand pension plans to identify key portfolio inefficiencies in 401(k) plans, attributing them either to the sponsor's menu design or to participants' own portfolio choices. We show that most sponsors offer efficient investment menus. However, many participants fail to construct efficient portfolios, leading to retirement wealth that could be one-fifth lower due to poor portfolio decisions. Because participants are the main source of inefficient DC portfolio choices, strategies targeting their portfolio choices, such as improved default investment strategies or advice programs, may help. Also, in sponsors' design of 401(k) menus, the number of options offered is less important than the range of funds provided.
\end{abstract}

Ning Tang

University of Pennsylvania

Wharton School

3620 Locust Walk

$3000 \mathrm{SH}-\mathrm{DH}$

Philadelphia, PA 19104

tangn@wharton.upenn.edu

Olivia S. Mitchell

University of Pennsylvania

Wharton School

3620 Locust Walk, St 3000 SH-DH

Philadelphia, PA 19104-6302

and NBER

mitchelo@wharton.upenn.edu
Gary R. Mottola

Vanguard Center for Retirement Research 100 Vanguard Boulevard, M38

Malvern, PA 19355

gmottola@vanguard.com

Stephen Utkus

Vanguard Center for Retirement Research 100 Vanguard Boulevard, M38

Malvern, PA 19355

steve_utkus@vanguard.com 


\title{
The Efficiency of Sponsor and Participant Portfolios Choices in 401(k) Plans
}

\author{
Ning Tang, Olivia S. Mitchell, Gary R, Mottola, and Stephen P. Utkus
}

With the growing numbers of investors and assets in 401(k) plans, as well as their increasingly prominent role in the financing of retirement, ${ }^{1}$ renewed attention has turned to the question of whether $401(\mathrm{k})$ portfolios are efficient. All else equal, for a given level of risk and return, better diversified portfolios would be expected to yield more retirement wealth than poorly diversified holdings. As a result, the question of how well these assets are invested is of substantial interest to policymakers and plan sponsors who oversee the system, as well as participants who anticipate using these resources as a source of income in retirement.

Portfolio performance in 401(k) plans depends on two factors: the choice of investment menu by plan sponsors, and the investment choices made by participants. Previous work has suggested that a large number of plan menus may be inefficient, reducing long-term wealth accumulation by around half (Elton, Gruber, and Blake or hereafter EGB, 2006; Angus, Brown, Smith, and Smith, 2007). But those conclusions may be questions due to their reliance on small and specialized datasets.

At same time, several studies have highlighted the behavioral biases and financial literacy constraints that appear to hinder participant decision-making. Some plan participants appear to use naive allocation strategies (Benartzi and Thaler, 2001; Agnew, 2002); others exhibit inertia in asset allocation and rebalancing (Ameriks and Zeldes, 2004; Agnew, Balduzzi, and Sunden, 2003); and still others are subject to framing and default effects in investment choices (Benartzi

\footnotetext{
${ }^{1}$ Private-sector DC retirement programs covered over 50 million active participants and held assets over \$2 trillion as of 2008 (ICI, 2009). DC plans are expected to be the primary source of retirement funding for a substantial fraction of future U.S. retirees (Poterba, Venti and Wise, 2007).
} 
and Thaler, 2002, Karlsson, Massa, and Simonov, 2007). Plan participants also display low levels of financial literacy and investment savvy (Hancock, 2002, Lusardi and Mitchell, 2007; Van Rooij, Kool and Prast, 2007); build poorly diversified portfolios (Mottola and Utkus, 2008); overinvest in company stock (Liang and Weisbenner, 2002; Huberman and Sengmueller, 2004; Benartzi, Thaler, Utkus and Sunstein, 2007); and follow their peers (Duflo and Saez, 2002). In previous work, we have also found that excessive trading in 401(k) plans is costly (Yamaguchi, Mitchell, Mottola, and Utkus, 2006). ${ }^{2}$ Despite this inventory of possible decision-making errors, few of these studies have attempted to quantify the extent of efficiency losses in the 401(k) context.

This paper distinguishes efficiency losses arising from the sponsor's investment menu design, versus participant portfolio choices. Our study builds on a dataset encompassing over one thousand firms and nearly one million participants, a substantially larger sample than previous available to other studies. With both plan-level data and as well individual participant holdings, we are uniquely able to separately identify and measure the size of diversification losses results from these two distinct portfolio decisions.

To preview our findings, we show that, contrary to previous studies, the overwhelming majority of 401(k) plan menus in our sample are efficiency when compared to a global market portfolio. Thus, participants could construct a mean-variance efficient portfolio in virtually all of the plans we analyzed. Nevertheless, the real-world participants in our dataset fall short of exploiting the efficient menus provided to them, failing to diversify adequately as measured by return losses and portfolio shares of idiosyncratic risk. We estimate that retirement wealth over a 35-year worklife might be reduced by as much as one-fifth due to participant diversification

\footnotetext{
${ }^{2}$ EGB (2007) compare participant portfolios with alternative portfolios formed by a naive $(1 / N)$ allocation strategy.
} 
errors. Indeed, employees' actual portfolios yield worse results than what could be obtained from a simple naïve allocation, where account balances would be divided evenly across the offered menu. For this reason, we conclude that efforts to improve 401(k) portfolio efficiency would best focus on improving participant portfolio choices through such strategies as greater use of default investing or portfolio advice services. Also, while sponsors generally construct efficient menus, we note that efficiency of an investment menu is less about offering large numbers of funds and more about choosing a limited number of options diversified across the capital markets.

In the remainder of the paper, we first describe the data and then assess the degree of both plan and individual portfolio efficiency. Next, we investigate the factors which influence portfolio performance/efficiency. A final section concludes.

\section{Empirical Overview}

Our dataset consists of $401(\mathrm{k})$ plans managed by Vanguard, a leading 401(k) administrator and mutual fund investment manager. Plan-level data include both the number and type of investment choices offered, total assets under management, numbers of participants accounts, plan type, ${ }^{3}$ and the monthly total return for each fund for the seven years prior. $^{4}$ Participant data include information on active accounts including account balances and amounts held by the fund, contribution sources (employer or employee), and participant sociodemographics (age, sex, plan tenure, non-retirement financial wealth, household income,

\footnotetext{
${ }^{3}$ Most of the plans are 401(k) plans in for-profit firms; there are also a few 403(b) plans for the non-profit sector.

${ }^{4}$ Monthly returns cover the period December 1997 through December 2004. In a handful of cases, some funds have fewer than 85 months of return observations.
} 
homeownership status, and whether the participant had web access). ${ }^{5}$ Our sample includes 986,949 participants in 1,003 plans observed in December 2004.

Table 1 summarizes characteristics of the plans and investment menu offerings in our sample. The average 401(k) plan had 1,222 participants holding \$73 million in assets (Panel A). Virtually all sponsors provided access to the range of broad asset classes, including short- and longer-duration fixed income options, balanced, lifecycle or similar options, and equity options (Panel B). Domestic active and index equity options were the most prevalent option (Panel C), followed by money market and stable value options. Company stock was offered in 11 percent of plans, and a brokerage window in only two percent of the plans.

\section{Table 1 here}

As shown in Table 2, the mean and median plan in our sample offered participants about 14 different investment choices in their 401(k) plans, consistent with other studies examining investment menus. ${ }^{6}$ Figure 1 reveals the dispersion, from a low of 3 to a high of 59. A typical plan offered about four actively-managed domestic equity funds, three actively-managed balanced funds, and just over two indexed domestic equity choices as the most common options.

Figure 1 and Table 2 here

Using a much smaller longitudinal data set Brown, Liang, and Weisbenner (2007) suggest that over time, the fraction of equity options in 401(k) plans has grown and most of the newly-added funds were of the actively-managed variety. They also indicate that this

\footnotetext{
${ }^{5}$ Active accounts are those with non-zero contributions over a 24-month window prior to our analysis (for the 24 months of 2003 and 2004). Data from IXI Corporation are used to impute non-retirement household financial wealth and household income is imputed by Axiom for 2003 using participant ZIP codes. Those who have elected to obtain plan information via the internet are defined as having web access.

${ }^{6}$ All data are as of as of December 2004. Using 2002 data, Brown, Liang and Weisbenner report a mean of 14 plan options based on a sample of firms filing 11-Ks; in 2004, the Profit-sharing/401(k) Council of America reported an average number of options of 17-18. Our figure is larger than the eight in EGB's (2006) older data on 401(k) plans surveyed in 2001 by Moody’s Investor Service.
} 
development might be costly to participants, if the index funds are less expensive and outperform higher-cost actively managed funds. In Figure 2, we array a cross-section of the funds in our sample according to the number of menu options and their investment management style (active versus passive). Here we see that as the total number of funds increases in the cross-section, domestic equity funds do indeed become more common, whether of the index or active variety. Also active strategies are more prevalent than index strategies, and larger plans offer more active equity choices than smaller plans, though they also provide more index funds. For example, a plan with a small menu might offer a broad-based domestic index fund and access to a handful of actively equity funds; meanwhile, a plan with a more complex menu might also offer large-, mid- and/or small-capitalization components of the index, along with even greater choice of active portfolios.

Figure 2 here

Turning to participants and their portfolio allocations, Panel A of Table 3 summarizes demographic characteristics. ${ }^{7}$ The mean participant is 45 years old, male, with annual household income of about $\$ 86,000$. Non-retirement wealth amounts to about $\$ 42,000$; most participants (96 percent) own a home; and almost half (45 percent) of them have web access. Panel B describes participant portfolios, where the mean $401(\mathrm{k})$ plan balance is $\$ 63,000 .^{8}$ On average, participants select 3.7 funds for their portfolio and hold the majority (88) percent of their balances in risky assets (defined here as any equity or bond market asset with a fluctuating

\footnotetext{
${ }^{7}$ Table 3 is computed for 986,614 participants; we lose a few participants because of missing demographic data. The efficiency measure used requires some nonzero risk exposure. All portfolio data is based on account balances.

${ }^{8}$ These figures are similar to a much broader sample from ICI (2008), where the average age is 44 and the mean balance is $\$ 65,000$.
} 
market value). The average participant held 28 percent of assets in index funds (either indexed bonds, equities or balanced options). ${ }^{9}$

Table 3 here

Plan and participant fund choices are reviewed in Figure 3, where we note a considerable association between fund types offered and selected. ${ }^{10}$ It may be that plan sponsors offer the options that participants demand, or conversely, that participants naively allocate their assets across the funds on the menu. There is evidence of overinvestment in company stock: that is, people hold a much higher share of company stock than is offered (perhaps influenced by sponsors who direct a portion of employer contributions to employer stock). Participant portfolios here tend to be dominated by domestic equity funds, either actively- or passivelymanaged, as well as actively-managed balanced funds. Lastly, participants tend to select actively-managed instead of index funds, except in the case of bonds. This may be partly due to the recent growth of actively-managed balanced funds.

Figure 3 here

\section{Tests for Plan Menu Efficiency}

To assess the efficiency of plan sponsor menu choices, we first compare existing plan menus with market benchmarks. Because we evaluate the efficiency of risky portfolios, our

\footnotetext{
${ }^{9}$ Thus, the average participant held 12 percent in money market or stable value assets, 28 percent in indexed assets (stocks, bonds or balanced strategies), and the remaining 60 percent in active strategies (stocks, bonds or balanced strategies).

${ }^{10}$ These participant allocations are comparable to those reported by the EBRI/ICI Participant Data Collection Project (ICI, 2008). In our sample, equity funds account for 52 percent of the assets; balanced funds 19 percent; bond funds 8 percent; company stock 9 percent; and money market and stable value funds 12 percent. By comparison in the EBRI/ICI sample, equity fund and balanced fund allocations for the same year at 46 percent and 8 percent; bonds 10 percent; company stock 15 percent; and money market and stable value funds 16 percent.
} 
analysis is centered on the bond, equity, and balanced fund options held by each plan. ${ }^{11}$ We measure plan-level efficiency in three ways. The first efficiency test applies the intersection or “spanning” test developed by DeRoon, Nijman and Werker (2001). This test classifies plans as either efficient or not based on how well they cover or span the global (liquid) capital markets. However, this test does not provide a measure of how far a plan might fall from being efficient. Accordingly, we provide two additional efficiency measures used in Calvet, Campbell and Sodini (hereafter CCS, 2007): a plan-specific relative Sharpe ratio loss (RSRL) and a plan's idiosyncratic risk share.

The analysis of both plan sponsor and participant decisions draws on a seven-year (84month) reference period from 12/97-12/04 to develop the optimal or tangency portfolio offered by the global capital markets during this period; plan sponsor fund selections and participant fund choices are then compared with this global benchmark. For this period, as a longer historic period from '79-04, Table 4 reports historic excess returns (versus Treasury bills) and standard deviation for various asset classes. One characteristic of our reference period is that investors experienced a lower equity risk premium for U.S. stocks, of one percent for large-capitalization growth stocks and five percent for large-capitalization value stocks, versus 7.5 percent and 9 percent, respectively over the longer period. A second aspect is a distinctive bias toward value stocks, while a third is higher stock market volatility and lower bond market volatility. While our overall results should be interpreted in light of these characteristics, our reference period remains a useful benchmark for analyzing the relative returns of plan sponsor menus and participant portfolios versus a global market benchmark, because all are being evaluated by the same

\footnotetext{
${ }^{11}$ Hence assets with a stable value (money funds and stable value funds) are excluded. Money market and investment contract funds are excluded as non-risky assets. Brokerage option investments are also excluded as we cannot observe their returns (only 2 percent of plans offer these). Returns on mutual funds are computed after expenses, while all other index returns are before expenses.
} 
yardstick. In the worst case, the efficiency losses we report below are likely to be lower-bound estimates.

\section{Table 4 here}

The "spanning" test of efficiency. The first test of plan sponsor menu efficiency considers whether a given plan's menu could be made more efficient by introducing investment classes currently excluded from the plan menu. As in EGB (2006), we construct a global market benchmark composed of eight commonly-accepted market indexes which "span” the world's liquid stock and bond markets. The eight indexes include four domestic equity indexes following the Fama-French equity style classification (Russell 1000 Growth, Russell 1000 Value, Russell 2000 Growth, and Russell 2000 Value Indexes); two domestic bond indexes based on credit quality (Lehman Aggregate Index for the investment-grade bond market and Credit Suisse First Boston High Yield for the non-investment-grade market); ${ }^{12}$ one international equity index (MSCI EAFE Index); and one international bond index (JP Morgan Global Government Bond Non-US\$ Index). Finally, the one-month Treasury-bill rate is taken as risk-free interest rate.

For each plan examined over our 84-month reference period, we regress $r_{i, t}$, the excess returns of the $i$ th benchmark index $(i=1,2 \ldots 8)$ over Treasury bills in a given month, on the monthly returns on the subset of funds held by the plan, $R_{t}$ :

$$
r_{i, t}=\alpha_{i}+\beta_{i} R_{t}+\varepsilon_{i, t}
$$

In this formulation, $\alpha_{i}$ is the Jensen's alpha from regression on ith benchmark index. Under this test of efficiency, there are short sale constraints for both funds in a plan and market benchmark index. As short-sales are not allowed for market benchmark index, if none of the $\alpha_{i}$ are

\footnotetext{
${ }^{12}$ Blake, Elton and Gruber (1993) suggest including a high-yield bond index to capture differences in return across bond funds.
} 
statistically significantly positive, we could conclude that performance of funds under the plan $R_{t}$ cannot be improved by holding a long position in any of the eight market benchmark indexes. $^{13}$

Our results are reported in Table 5, where Panel A indicates that 94 percent of the 1,003 plans studied are efficient compared to market benchmarks, by this test. This implies that most 401(k) plan participants, in the majority of plans, could invest efficiently if they wisely exploited the choices made available to them by their employer. Even plans with relatively few investment choices can still be as efficient as our global benchmark portfolio, as long as they are carefully chosen-a point we return to in the next section.

Table 5 here

Our finding of exceptionally high levels of 401(k) menu efficiency differs from EGB’s earlier (2006) result, where efficiency ratings were worse. Two factors may account for this difference. First, the EGB sample was a few years older, from 2001, and sponsors are likely to have boosted the range of options provided by 2004. Second, their plans were smaller and far less diversified than ours: for instance, only 71 percent plans in the EGB sample offered domestic bond funds whereas 97 percent of our sample did so.

Relative Sharpe ratio loss. Our second measure of plan sponsor menu efficiency is the relative Sharpe ratio loss, which measures the extent of economic loss from holding an inefficient portfolio in the mean-variance framework (CCS, 2007). In our case, the portfolio to be measured is the tangency portfolio of a plan based on the fund options it offers. The benchmark portfolio

\footnotetext{
${ }^{13}$ The specific test statistic is: $\xi=\min _{\{\alpha \leq 0\}}(\hat{\alpha}-\alpha)^{\prime} \operatorname{Var}[\hat{\alpha}]^{-1}(\hat{\alpha}-\alpha) \quad$, where $\hat{\alpha}$ is an $8^{*} 1$ vector of estimated Jensen's alphas. For the critical value used in the test, we adopt the lower/upper bounds suggested by Kodde and Palm (1986) and run 1,000 simulations to see if the test statistic falls within the critical value bounds.
} 
is defined as the tangency portfolio formed by the eight market benchmark indexes introduced earlier. For portfolio $p$, the relative Sharpe ratio loss is defined as:

$$
R S R L_{p}=1-\frac{S_{p}}{S_{B}}
$$

where $S_{p}=\frac{\hat{\mu}_{p}}{\hat{\Sigma}_{p}}$ is the Sharpe ratio of tangency portfolio of funds held under the plan; the moments of the plan are estimated by the capital asset pricing model (CAPM; see the Appendix for details); and $S_{B}$ is the Sharpe ratio of tangency portfolio of eight benchmark indexes used in the efficiency test. The moments of the eight indexes are also estimated using CAPM. From equation (2), we can see that the lower the ratio, the closer are the portfolio and benchmark Sharpe ratios. In other words, when the two Sharpe ratios are exactly equal, the right hand term is zero and there is no relative efficiency loss.

The first row of Panel B in Table 5 provides the distribution of relative Sharpe ratio losses of the tangency portfolio formed by the available funds in each plan. Overall, the 401(k) plans in our analysis sample perform very well compared to the benchmark portfolio: the mean relative Sharpe ratio loss of three percent is quite low. In other words, the Sharpe ratio of the tangency portfolio of an average plan is 97 percent of that of the benchmark portfolio ( 1 - .97/1 $=.03$ ). Furthermore, the sample plans vary little in terms of their relative Sharpe ratio losses: even at the 90th percentile, the loss measure is only five percent. A small group of plans is less well-structured; thus at the $99^{\text {th }}$ percentile, the efficiency loss is 66 percent. ${ }^{14}$

Idiosyncratic risk share. Our third measure of plan menu efficiency is idiosyncratic risk share measures—namely the percentage of portfolio total variance attributable to idiosyncratic risk.

\footnotetext{
${ }^{14}$ There appear to be two main sources of inefficiency. One is that these plans lack fixed income funds, which we note again below. A second is that many of the most inefficient plans have small menus (the mean number of options is 8) with an overallocation to active equity or balanced funds.
} 
Idiosyncratic risk is defined as the risk that can be diversified away; it is non-market risk (CCS 2007), or specifically:

$$
\operatorname{IRS}_{p}=\frac{\hat{\Sigma}_{\text {idio,p }}}{\hat{\Sigma}_{p}}
$$

where $\hat{\Sigma}_{\text {idio,p }}$ is the idiosyncratic risk of the tangency portfolio of funds held by the plan, and $\hat{\Sigma}_{p}$ is the total risk of the tangency portfolio. The lower the ratio, the more diversified a plan is against specific or non-market risk.

The distribution of idiosyncratic risk shares across our sample of plans is displayed in the second row in Panel B, of Table 5. On average, the idiosyncratic risk is three percent; in other words, only three percent of the total variance of a plan's tangency portfolio is diversifiable risk. Even at the $90^{\text {th }}$ percentile, the ratio is still below eight percent, which indicates a very high diversification level. It is interesting that a handful, only one percent of the plans, do not perform well according to this measure, having an idiosyncratic risk share of over 21 percent. $^{15}$

Separately, we calculate relative Sharpe ratio losses and idiosyncratic risk shares for the two groups of plans, efficient and inefficient, that emerge from the first "spanning" test. Inefficient plans are not very different from efficient plans in the aggregate, suggesting that small changes to many of the inefficient plans could improve their characteristics. Specifically, the inefficient six percent of plans had a relative Sharpe ratio loss of four percent and idiosyncratic risk shares of five percent, versus three and three percent for efficient plans. However, as noted above, a small percentage of plans has very large Sharpe ratio losses or shares of idiosyncratic

\footnotetext{
${ }^{15}$ As in the analysis of Sharpe ratio losses, these plans' inefficiency appears due to the absence of bond funds, along with to a limited extent active equity and balanced fund choices in small menus.
} 
risk and modest changes in these plans are unlikely to result in a shift from an inefficient to an efficient plan.

In sum, we conclude that virtually all of the plan menus offered in this sample are quite efficient in terms of mean-variance efficiency measures, as they are well diversified. By and large, plan sponsors appear to construct menus that afford participants the opportunity to build well-diversified portfolios. Even among the few inefficient plans, many do not far terribly short and these shortfalls can be remedied by modest menu changes.

\section{Tests for Participant Portfolio Efficiency}

Next we turn to the efficient of the individual portfolios constructed by participants. In contrast to the prior section where our analysis is conducted at the plan level, the focus here shifts to the individual portfolios constructed by each participant. We use three measures to evaluate the efficiency of participant portfolio choices:

(1) Participant total return loss, or the return loss in the participant's portfolio compared to what he could have optimally obtained in a global capital markets benchmark, independent of the menu choices offered to him or her; this measure summarizes losses due to inefficient portfolio choices by both the sponsor and the participant;

(2) Participant relative return loss, or the return loss in the participant's portfolio compared to the set of investment choices offered to him or her; these are losses due purely to participant (and not plan sponsor) investment errors; and,

(3) Participant idiosyncratic risk share, or the extent to which participant portfolio returns arise from market (nondiversifiable) versus specific (diversifiable) risk. 
Participant total return loss. A participant's “total return loss” is the shortfall in portfolio return experienced by a participant's actual portfolio, given his choice of risk, compared to the return he could have realized in the broader global capital markets for the same level of risk. Assume that a participant in plan $j$ chooses a portfolio $p$ with risk level $\sigma_{p}$. The monthly total return loss for his portfolio is:

$$
R L_{p}=w_{p}\left(\mu_{B}-\mu_{p}\right)
$$

where $\mu_{B}$ is the best return that could be optimally attained at risk level $\sigma_{p}$ using the eight market benchmark indexes representing the liquid global capital markets ; and $\mu_{p}$ is the actual return of the participant's portfolio for the same risk level $\sigma_{p}$. The term $w_{p}$ refers to the risky asset share, which is calculated using the balances in each individual participant's portfolio. This weight permits the measure to reflect the fact that participants holding poorly performing risky assets might still be close to the efficient frontier if they their risky exposure is small. The unscaled total return loss before weight adjustment is demonstrated by the line segment A in Figure 4, where $\left(\mu_{p}, \sigma_{p}\right)$ is the actual portfolio chosen by the participant, and the outer curve is the efficient frontier formed by the eight market benchmark indexes.

Figure 4 here

To measure this in practice, we use the distribution of the monthly participant total return losses for the 986,949 individual portfolios in 1,003 plans, depicted in Figure 5. The mean monthly total return loss is 0.1093 percent or approximately 11 basis points; about three percent of the participants have a return loss of zero, while one percent of participants have a total return loss of over 0.4 percent or 40 basis points per month. To put these results in context, if one expected a diversified $401(\mathrm{k})$ portfolio to generate an annual real return of five percent after 
expenses, the typical participant would be predicted to forfeit 23 percent of his expected retirement wealth over a 35-year worklife by having a less-than-adequate plan investment menu and by failing to diversify adequately. ${ }^{16}$ Wealth losses would be even greater for those in the fifth or first percentile cases.

Figure 5 here

Participant relative return loss. Next we compute the participant total return loss, which measures the total shortfall due to both plan sponsor menu and participant investment choices. The participant relative return loss reflects only the inefficiency resulting from poor participant investment choices within a given plan. We evaluate this by computing the best return obtainable in plan $j$ for risk level $\sigma_{p}$ or is $\mu_{B}$ in equation (4), keeping all other factors constant. That is, we calculate the return shortfall of each actual individual portfolio compared to the best return that could be obtained in the same plan for the same risk level. Thus, line segment B in Figure 4 reflects the un-scaled relative return loss before weight adjustment $w_{p}$ in equation (6), where the interior curve is the efficient frontier formed by funds available in a plan. (The difference between segments A and B measures the inefficiency caused by menu restrictions.)

Panel B in Figure 5 sketches the distribution of monthly relative return losses for the same participants, where we see that these losses are concentrated around a monthly mean loss of 0.079 percent or 8 basis points per month. At the extremes, some six percent of the participants have a return loss of zero, while one percent of participants experience a return loss of over 0.29 percent or 29 basis points per month. The mean monthly relative return loss of eight basis points would imply 18 percent less in retirement wealth over a 35-year saving period.

\footnotetext{
${ }^{16}$ We assume a participant saves for 35 years, has an initial salary of $\$ 30,000$ a year, experiences real wage growth of 1 percent per year and real after-fee returns of 5 percent per year (a monthly return of 41 basis points), and contributions 9 percent of pay to his $401(\mathrm{k})$ account (6 percent employee and 3 percent employer contribution). Terminal wealth is $\$ 276,700$ with a 5 percent real return; $\$ 212,100$ with the reduced return.
} 
From this measure, we conclude that most participants fail to construct an optimal portfolio from the menu offered to them by their plan sponsor, and an important subset of participants suffers a substantial return loss, undermining long term wealth accumulation. On average, the relative return loss from participant investment mistakes accounts for three-quarters (76 percent) of the total return loss, indicating that participant portfolio choice inefficiency is the main source of underperformance. About one-quarter of the efficiency loss could be addressed by better plan menus.

Participant idiosyncratic risk share. Our third participant measure is the idiosyncratic risk share of an individual participant's portfolio, defined as the ratio of idiosyncratic risk to the portfolio's total variance. Figure 6 on the distribution of this measure shows that the mean value of the idiosyncratic risk share is 0.187 , much higher than the 0.03 share in the average plan. There is a wide range in idiosyncratic risk shares from 0.001 to 0.997 ; also the top five percent of participants has an idiosyncratic risk share of more than 0.77 , meaning that 77 percent of the portfolio variance is not rewarded by higher expected return. By this measure, many participants also take a substantial amount of specific or idiosyncratic risk, either because they hold activelymanaged funds or company stock in their portfolios.

Figure 6 here

Actual portfolios versus naïve allocation strategies. As a measure of the costs of poor portfolio choices, we compare participants' actual portfolio choices with what would happen if they used a naïve diversification strategy, such as simply dividing their portfolio among all available funds using a $1 / N$ strategy. To do so, we evaluate the relative return loss and idiosyncratic risk share of a hypothetical participant in each plan who follows a naive allocation strategy, and compare the results to workers' actual portfolio characteristics. Results appear in Figure 7, which confirm that 
actual individual portfolios underperform even the naive allocation strategy. Individual portfolios have a slightly higher relative return loss (0.079 vs.0.076 percent per month). But they also have a much higher idiosyncratic risk share (0.187 vs. 0.04), suggesting that individual portfolios are more highly exposed to non-market risk through active funds and company stock than would hold with a simple naïve strategy.

Figure 7 here

\section{Determinants of Portfolio Efficiency: Behavioral and Plan Menu Effects}

Given the meaningful inefficiencies we have identified in portfolio choices in 401(k) and other DC plans, what might be done to enhance investment patterns? Two approaches might be taken to improve 401(k) investment performance: improving investment menu decisions by plan sponsors, or altering individual participant investment choices. In this section, we examine factors contributing to the variation in portfolio performance across plan investment menus and participant portfolios, so as to explore what characteristics contribute to portfolio efficiency in each setting. In particular, we seek to learn whether simply adding more funds, as many plan sponsors are doing today, is likely to boost plan efficiency at the menu level, and, at the participant level, what types of asset allocation changes are needed to improve diversification levels.

Plan sponsor menu effects. To determine what plan sponsor menu decisions might influence plan efficiency, we run multivariate regressions of the form:

$$
\text { Perform }_{j}=\alpha+\beta_{1} \text { PLANCOMP }_{j}+\beta_{2} \text { PLANCHAR }_{j}+\beta_{3} \text { PRTCHAR }_{i, j}+\varepsilon \text { (5) }
$$

where the dependent variable Perform $_{j}$ is a vector of outcomes of the previous measures of plan-level efficiency. Specifically, the vector includes: a $(0,1)$ indicator with the value of 1 if the 
plan is efficient (0 if not); the plan's relative Sharpe ratio loss; and the plan's idiosyncratic risk share. The explanatory variable PLANCOMP represents a vector of plan characteristics including the number of options offered and the availability of different types of risky funds. A second vector of explanatory variables PLANCHAR is used to control for plan characteristics such as plan size (measured by the natural logarithm of the number of accounts, the log of the plan's total assets, and contribution source). We also control on PRTCHAR, which captures participant characteristics such as age, sex, plan tenure, and income as well as asset indicators - some of which are likely correlated with financial sophistication (the natural logs of household income and non-retirement financial wealth, as well as homeownership and web access).

Table 6 shows the results of these multivariate models, where the first is a Probit regression on whether or not the plan is efficient, and the other two are OLS regressions on the relative Sharpe ratio loss and idiosyncratic risk share. The first equation indicates that simply having more funds listed on the menu does not improve plan efficiency. The second suggest that adding funds does reduce the relative Sharpe ratio loss and idiosyncratic risk share. For example, at the mean, adding one fund reduces these factors by -0.4 percent, or more than 10 percent of the mean loss and mean risk share. The marginal benefit from adding more options is also decreasing, as indicated by the concave relationship from the variable, the number of options squared. This result suggests that adding more options may improve menu design but at a declining rate.

Table 6 here

Figure 8 reinforces this conclusion. It shows the average relative Sharpe ratio loss and idiosyncratic risk share calculated earlier, for plans arrayed by the number of funds offered. The measures fall dramatically until about ten options and then declines at a much smaller rate for 
larger menus. It would seem that a well-chosen menu of 10 options achieves much of the efficiency gains to be realized.

Figure 8 here

In terms of investment options, the plan efficiency test (the first column in Table 6) implies that indexed domestic equities and bonds would the main asset classes that inefficient plans would have to add. Since most of the inefficient plans are small in size, it would appear that the limited number of index and active equity and balanced choices in their line-up are insufficient for adequate diversification.

Participant portfolio decisions. We examine the determinants of participant portfolio choices using the following multivariate regression:

$$
\operatorname{PERFORM}_{i, j}=\alpha+\beta_{1} \operatorname{INVEST}_{i, j}+\beta_{2} \operatorname{DEMO}_{i, j}+\beta_{3} \operatorname{PLAN}_{j}+\varepsilon_{i, j}
$$

For the ith participant in the $j$ th plan, dependent variables Perform $_{i, j}$ refer to the portfolio relative return losses as well as idiosyncratic risk share calculated previously at the participant account level. INVEST $T_{i, j}$ refers to a vector of individual investment characteristics including the number of funds chosen, company stock share and shares of eight types of funds: index and active versions of domestic equity, international equity, balanced funds and bond funds. $D E M O_{i, j}$ refers to individual demographic characteristics such as the participant's age, income, non-retirement wealth, and web access. $P L A N_{j}$ refers to a vector of plan-specific characteristics which affect participant performance and are common among all participants in the same plan. ${ }^{17}$

\footnotetext{
${ }^{17}$ To eliminate unobserved plan fixed effects, Plan $_{j}$, we transformation the data as follows:

$\left(\right.$ Perform $\left._{i, j}-{\overline{\text { Perform }_{j}}}\right)=\alpha+\beta_{1}\left(\right.$ Invest $\left._{i, j}-{\overline{\text { Invest }_{j}}}\right)+\beta_{2}\left(\right.$ Demo $\left._{i, j}-{\overline{\text { Demo }_{j}}}_{j}\right)+\varepsilon_{i, j}$, where

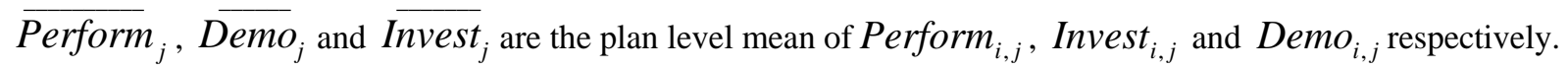


Table 7 reports results for our two dependent variables, the participant's relative return loss and the participant's idiosyncratic risk share. Holding more funds in a portfolio does reduce return losses, but only by an economically tiny effect (by two-hundreds of a basis point versus a mean loss of eight basis points). However, owning more funds does reduce idiosyncratic risk meaningfully_adding an additional fund reduces such risk by six percent. Second, participant portfolios can best be improved from a return loss perspective by diversifying into all asset classes other than the reference category, domestic indexed equities. In terms of the most important asset class to consider, it would be bond funds, active or passive. Yet at the same time, as measured in the second regression, such portfolios do (at the margin) increase idiosyncratic risk relative to domestic index holdings.

\section{Table 7 here}

Finally, we find that in terms of participant characteristics, those who access their accounts through the internet have lower return losses, but also higher exposure to non-market risk. At the margin, young and higher-income participants have smaller return losses, as do those with more wealth outside their retirement plan. In any event the measured economic effects are quite small.

\section{Conclusions and Discussion}

We consider the quality of portfolio investment choices made in 401(k) and other U.S. defined contribution plans using a rich new dataset of more than 1,000 plans and nearly one million participants. Our assessment distinguishes between the effects arising from the plan sponsor’s menu design decisions, versus those arising from the portfolio decisions of plan participants. Overwhelmingly, we find that the plans in our sample are efficient compared to a 
global capital markets benchmark; we classified 94 percent of plans as efficient, and only six percent as inefficient. Many of the inefficient plans could make small changes to improve diversification levels by adding domestic equity and bond portfolios to their existing line-ups. Moreover, simply adding more investment options does not necessarily lead to large gains in efficiency. Once a minimum number of well-chosen funds is included in a pension plan menu (roughly 10 or so), most of the diversification gains are likely to have been realized.

At the same time, while sponsors are able to construct highly-efficient plan menus, many participants err by investing ineffectively and by failing to exploit the diversification opportunities offered within their plans. On average, they forfeit eight basis points of potential return per month based on our analysis period. Because of the long-term effects from compounding such errors, small mistakes over time can be important, reducing retirement wealth by as much as one-fifth over a 35-year worklife. These findings complement the growing literature on investor behavioral biases, investment errors, and financial illiteracy.

One avenue for improving participant portfolios is to improve financial education and investment literacy levels. But education programs require pro-active decision-making by participants, and it is by now well established that inertia is a dominant decision heuristic for many participants. Accordingly, sponsors and policymakers will want to consider efforts to improve participant portfolios through other means. These might include better default investment strategies as well as investment advice programs. The U.S. Department of Labor, acting under the 2006 Pension Protection Act, has authorized a series of "qualified default investment alternatives” (QDIAs) including balanced funds, target-date strategies, and managed account advisory services. ${ }^{18}$ Greater adoption of such strategies by plans and by participants

\footnotetext{
${ }^{18}$ For a discussion of these see Mitchell, Mottola, Utkus and Yamaguchi (2009).
} 
(whether by active choice or by default) is likely to improve portfolio efficiency metrics within 401(k) plans.

Although we focus here mainly on behavior in individual retirement accounts, our research has implications for portfolio choice and wealth outcomes more generally. Today almost half of all Americans have at least some assets in tax-deferred accounts, and furthermore, asset allocations prove to be quite similar inside and outside tax-deferred accounts (Bergstresser and Poterba 2004). Consequently, it is likely that the inefficiencies observed in the retirement context are replicated outside the 401(k) setting. 


\section{References}

Agnew, Julie, Pierluigi Balduzzi, and Annika Sunden. 2003. "Portfolio Choice and Trading in a Large 401(k) Plan.” American Economic Review 93 (1), 193-215.

Agnew, Julie. 2002. "Inefficient Choices in 401(k) Plans: Evidence from Individual Level Data.” Presented at the $4^{\text {th }}$ Annual Joint Conference for the Retirement Research Consortium "Directions for Social Security Reform,” May 2002, Washington, D.C.

Ameriks, John, and Stephen P. Zeldes. 2004. "How do Household Portfolio Shares Vary with Age?” TIAA-CREF working paper.

Angus, John, William O. Brown, Janet Kiholm Smith, and Richard L. Smith. 2007. "What's in Your 403(b)? Academic Retirement Plans and the Costs of Underdiversification." Financial Management, Summer 2007, 1-38.

Benartzi, Shlomo, and Richard H. Thaler. 2001. "Naïve Diversification Strategies in Defined Contribution Savings Plans.” American Economic Review, 91 (1), 79-98.

Benartzi, Shlomo and Richard H. Thaler. 2002. "How Much Is Investor Autonomy Worth?" Journal of Finance. August. 57(4). 1593-1616.

Benartzi, Shlomo, Richard H. Thaler, Stephen P. Utkus and Cass R. Sunstein. 2007. “The Law and Economics of Company Stock in 401(k) Plans.” Journal of Law and Economics, University of Chicago Press. 50(1): 45-79.

Bergstresser, Daniel, and James Poterba. 2004. “Asset Allocation and Asset Location: Household Evidence from the Survey of Consumer Finances.” Journal of Public Economics, 88 (9-10), 1893-1915.

Blake, Christopher R., Edwin J. Elton, and Martin J. Gruber. 1993. “The Performance of Bond Mutual Funds." Journal of Business, 66, 371-403.

Brown, Jeffrey R., Nellie Liang, and Scott Weisbenner. 2007. "Individual Account Investment Options and Portfolio Choice: Behavioral Lessons from 401(k) Plans.” Journal of Public Economics, 91 (10), 1992 - 2013.

Calvet, Laurent E., John Y. Campbell, and Paolo Sodini. 2007. "Down or Out: Assessing the Welfare Costs of Household Investment Mistakes.” Journal of Political Economy, 115 (5), 707-747.

DeRoon, Frans A., Theo E. Nijman, and Bas J.M. Werker. 2001. "Testing for Mean-Variance Spanning with Short Sales Constraints and Transaction Costs: The Case of Emerging Markets.” Journal of Finance, 56 (2), 721-742.

Duflo, Esther, and Emmanuel Saez. 2002. "Participation and Investment Decisions in a Retirement Plan: The Influence of Colleagues’ Choices.” Journal of Public Economics, 85 (1), 212-148.

Elton, Edwin J., Martin J. Gruber, and Christopher R. Blake. 2006. "The Adequacy of Investment Choices Offered by 401(k) Plans.” Journal of Public Economics, 90 (6-7), 1299-1314.

Elton, Edwin J., Martin J. Gruber, and Christopher R. Blake. 2007. "Participant Reaction and the Performance of Funds Offered by 401(k) Plans.” Journal of Financial Intermediation, 16 (2), 240-271.

Hancock, John. 2002. "Eighth Defined Contribution Plan Survey.” John Hancock Financial Services, Boston: John Hancock.

Huberman, Gur, and Paul Sengmueller. 2004. "Performance and Employer Stock in 401(k) Plans.” Review of Finance, 8, 403-443. 
ICI. 2008. “401(k) Plan Asset Allocation, Account Balances, and Loan Activity in 2007.” Investment Company Institute Research Perspective, 14 (3), 2008.

ICI, 2009. “The U.S. Retirement Market, 2008.” Investment Company Institute Research Fundamentals, 18(5), June 2009.

Karlsson, Anders, Massimo Massa, and Andrei Simonov. 2007. "Pension Portfolio Choice and Menu Exposure.” In: Madrian, Brigitte, Olivia S. Mitchell, Beth J. Soldo (eds.), Redefining Retirement: How Will Boomers Fare? Oxford: Oxford University Press, 248270.

Kodde, David A., and Franz C. Palm. 1986. "Wald Criteria for Jointly Testing Equality and Inequality Restrictions.” Econometrica, 54, 1243-1248.

Liang, Nellie, and Scott Weisbenner. 2002. "Investor Behavior and the Purchase of Company Stock in 401(k) Plans - The Importance of Plan Design.” Finance and Economics Discussion Series 2002-36. Washington: Board of Governors of the Federal Reserve System, 2002.

Lusardi, Annamaria and Olivia S. Mitchell. 2007. "Baby Boomer Retirement Security: The Roles of Planning, Financial Literacy, and Housing Wealth.” Journal of Monetary Economics. 54(1) January: 205-224.

Mitchell, Olivia S., Gary Mottola, Steve Utkus, and Takeshi Yamaguchi. 2009. "Menu Effects and Retirement Saving: The Impact of Life Cycle Funds on 401(k) Plan Portfolios." PRC Working Paper, Presented at the 2009 ASSA meetings, San Francisco.

Mottola, Gary R. and Stephen P. Utkus. 2008. "Red, Yellow and Green: Measuring the Quality of 401(k) Portfolio Choices.” In Overcoming the Savings Slump, Annamaria Lusardi, ed. University of Chicago Press, Chicago, IL. 2008. 119-139.

Poterba, James, Steven Venti, and David Wise. 2007. "Rise of 401(k) Plans, Lifetime Earnings, and Wealth at Retirement.” NBER Working Paper No. 13091.

Van Rooij, Maarthen C.J., Clements, J.M. Kool, and Henriette M. Prast. 2007. "Risk-Return Preferences in the Pension Domain: Are People Able to Choose?” Journal of Public Economics, 91 (3-4), 701-722.

Yamaguchi, Takeshi, Olivia S. Mitchell, Gary R. Mottola, and Stephen P. Utkus. 2006. "Winners and Losers: 401(k) Trading and Portfolio Performance.” Pension Research Council Working Paper No. 2006-26, The Wharton School. 
Table 1. Plan Characteristics: Size and Investment Menus

\begin{tabular}{lrr}
\hline A. Plan size & Mean & Median \\
\hline Plan assets (millions) & $\$ 73.4$ & $\$ 15.6$ \\
Plan participants & 1222 & 246
\end{tabular}

\section{B. Broad asset classes}

Plans offe ring

Any short-duration fixed income fund

$99.1 \%$

Any bond fund

$97.4 \%$

Any balanced fund

$96.5 \%$

Any equity fund

$99.9 \%$

C. Types of investment options

Plans offering

Short-duration fixed income

Money market fund

$74.6 \%$

Investment contract (stable value) fund

$50.2 \%$

Longer-duration fixed income

Index bond fund

$80.9 \%$

Active bond fund

$45.9 \%$

Equity funds

Index domestic equity fund

$99.2 \%$

Active domestic equity fund

$96.5 \%$

Any domestic fund

$99.9 \%$

Index international equity fund

$24.3 \%$

Active international equity fund

$84.2 \%$

Any internatioanl fund

$93.1 \%$

Other options

Company stock

$11.4 \%$

Brokerage option

$2.4 \%$

Source: Authors' computations. Note: Brokerage option permits employees to choose among thousands of funds and/or individual securities depending on plan; $\mathrm{N}=1,003$ plans. 
Table 2. Number of Investment Options per Plan: Mean, Share, and Distribution by Type

\begin{tabular}{lcc|ccccc}
\hline & $\begin{array}{c}\text { Mean } \\
\text { options } \\
\text { offe red }\end{array}$ & $\begin{array}{c}\text { Share of } \\
\text { plan } \\
\text { options }\end{array}$ & $\begin{array}{c}\text { 10th } \\
\text { percentile }\end{array}$ & $\begin{array}{c}\text { 25th } \\
\text { percentile }\end{array}$ & $\begin{array}{c}\text { Median } \\
\text { percentile }\end{array}$ & $\begin{array}{c}\text { 90th } \\
\text { percentile }\end{array}$ \\
\hline Total number of options per plan & 13.5 & $100 \%$ & 8 & 10 & $\mathbf{1 3}$ & 16 & 19 \\
Money market & 1.3 & $11 \%$ & 1 & 1 & $\mathbf{1}$ & 2 & 2 \\
Bond index & 0.9 & $7 \%$ & 0 & 1 & $\mathbf{1}$ & 1 & 1 \\
Bond actively managed & 0.8 & $5 \%$ & 0 & 0 & $\mathbf{0}$ & 1 & 2 \\
Balanced index & 0.1 & $1 \%$ & 0 & 0 & $\mathbf{0}$ & 0 & 1 \\
Balanced actively managed & 2.7 & $19 \%$ & 1 & 1 & $\mathbf{2}$ & 4 & 5 \\
Domestic equity index & 2.5 & $19 \%$ & 1 & 1 & $\mathbf{2}$ & 3 & 4 \\
Domestic equity actively managed & 3.8 & $28 \%$ & 2 & 2 & $\mathbf{3}$ & 5 & 7 \\
International equity index & 0.3 & $2 \%$ & 0 & 0 & $\mathbf{0}$ & 0 & 1 \\
International equity actively managed & 1.0 & $8 \%$ & 0 & 1 & $\mathbf{1}$ & 1 & 2 \\
Other & 0.2 & $1 \%$ & 0 & 0 & $\mathbf{0}$ & 0 & 1 \\
\hline
\end{tabular}

Source: Authors' computations. Note: $N=1,003$ plans 
Table 3. Participant Characteristics: Sociodemographics and Portfolio Attributes

\begin{tabular}{|c|c|c|c|c|c|c|}
\hline & Mean & $\begin{array}{c}\text { 10th } \\
\text { Percentile }\end{array}$ & $\begin{array}{c}25 \text { th } \\
\text { Percentile }\end{array}$ & Median & $\begin{array}{c}\text { 75th } \\
\text { Percentile }\end{array}$ & $\begin{array}{c}\text { 90th } \\
\text { Percentile }\end{array}$ \\
\hline \multicolumn{7}{|l|}{ Demographic characteristics } \\
\hline Age & 45 & 30 & 37 & 45 & 52 & 58 \\
\hline Male (yes=1) & $68 \%$ & $0 \%$ & $0 \%$ & $100 \%$ & $100 \%$ & $100 \%$ \\
\hline Household income & $\$ 86,227$ & $\$ 35,000$ & $\$ 62,500$ & $\$ 86,319$ & $\$ 87,500$ & $\$ 137,500$ \\
\hline Non-retirement wealth & $\$ 41,708$ & $\$ 0$ & $\$ 1,677$ & $\$ 7,280$ & $\$ 35,737$ & $\$ 111,683$ \\
\hline Web access (yes=1) & $45 \%$ & $0 \%$ & $0 \%$ & $\mathbf{0} \%$ & $100 \%$ & $100 \%$ \\
\hline Homeowner (yes=1) & $96 \%$ & $100 \%$ & $100 \%$ & $100 \%$ & $100 \%$ & $100 \%$ \\
\hline \multicolumn{7}{|c|}{ Individual portfolio characteristics } \\
\hline Number of funds chosen & 4 & 1 & 2 & 3 & 5 & 7 \\
\hline Average account balance ( $\$ 000)$ & $\$ 63.3$ & $\$ 2.3$ & $\$ 9.0$ & $\$ 28.2$ & $\$ 74.0$ & $\$ 158.3$ \\
\hline Index share in portfolio & $28 \%$ & $0 \%$ & $0 \%$ & $21 \%$ & $47 \%$ & $76 \%$ \\
\hline Risky share in portfolio & $88 \%$ & $53 \%$ & $85 \%$ & $100 \%$ & $100 \%$ & $100 \%$ \\
\hline
\end{tabular}

Source: Authors' computations. Note: A portfolio's risky share is the fraction held in equities or bonds either directly through an equity or bond fund or indirectly through balanced, lifestyle or lifecycle funds. $\mathrm{N}=986,614$ participants. 
Table 4. Asset Class Characteristics

\begin{tabular}{|c|c|c|c|c|}
\hline & \multicolumn{2}{|c|}{ Excess returns } & \multicolumn{2}{|c|}{ Standard Deviation $(\sigma)$} \\
\hline & $\begin{array}{l}\text { Mean } \\
\text { monthly }\end{array}$ & Annualized & Monthly & Annualized \\
\hline \multicolumn{5}{|l|}{ A. $1997-2004$ (reference period) } \\
\hline Russell 1000 Growth Index & $0.08 \%$ & $1.00 \%$ & $6.21 \%$ & $21.51 \%$ \\
\hline Russell 1000 Value Index & $0.42 \%$ & $5.19 \%$ & $4.55 \%$ & $15.75 \%$ \\
\hline Russell 2000 Growth Index & $0.30 \%$ & $3.61 \%$ & $8.31 \%$ & $28.79 \%$ \\
\hline Russell 2000 Value Index & $0.73 \%$ & $9.14 \%$ & $4.93 \%$ & $17.09 \%$ \\
\hline Lehman Aggregate Bond Index & $0.27 \%$ & $3.31 \%$ & $1.06 \%$ & $3.67 \%$ \\
\hline Credit Suisse First Boston High Yield Bond Index & $0.27 \%$ & $3.27 \%$ & $2.16 \%$ & $7.50 \%$ \\
\hline MSCI-EAFE Index & $0.27 \%$ & $3.35 \%$ & $4.67 \%$ & $16.17 \%$ \\
\hline J.P. Morgan Global Government Bond Non-US\$ Index & $0.37 \%$ & $4.52 \%$ & $2.54 \%$ & $8.80 \%$ \\
\hline Large-capitalization value premium & $0.34 \%$ & $4.18 \%$ & & \\
\hline Small-capitalization value premium & $0.44 \%$ & $5.53 \%$ & & \\
\hline \multicolumn{5}{|l|}{ B. $1979-2004$} \\
\hline Russell 1000 Growth Index & $0.60 \%$ & $7.48 \%$ & $5.22 \%$ & $18.08 \%$ \\
\hline Russell 1000 Value Index & $0.73 \%$ & $9.06 \%$ & $4.15 \%$ & $14.38 \%$ \\
\hline Russell 2000 Growth Index & $0.57 \%$ & $7.08 \%$ & $6.89 \%$ & $23.87 \%$ \\
\hline Russell 2000 ValueIndex & $0.86 \%$ & $10.88 \%$ & $4.78 \%$ & $16.54 \%$ \\
\hline Lehman Aggregate Bond Index & $0.25 \%$ & $3.09 \%$ & $1.78 \%$ & $6.18 \%$ \\
\hline Credit Suiss First Boston High Yield Bond Index & N/A & N/A & N/A & N/A \\
\hline MSCI-EAFE Index & $0.47 \%$ & $5.81 \%$ & $4.92 \%$ & $17.05 \%$ \\
\hline J.P. Morgan Global Government Bond Non-US\$ Index & N/A & N/A & N/A & N/A \\
\hline Large-capitalization growth premium & $0.12 \%$ & $1.58 \%$ & & \\
\hline Small-capitalization growth premium & $0.29 \%$ & $3.81 \%$ & & \\
\hline
\end{tabular}

Source: Authors' computations from data supplied by index providers. 
Table 5. Plan Menu Efficiency Measures

\author{
A. Spanning Test
}

\begin{tabular}{lr}
\hline \hline & \% of plans \\
\hline Efficent plans & $94 \%$ \\
Inefficient plans & $6 \%$ \\
Total & $100 \%$ \\
\hline \hline
\end{tabular}

B. Other Menu Performance Measures

\begin{tabular}{|c|c|c|c|c|c|c|c|c|}
\hline & Mean & $\begin{array}{r}1 s t \\
\text { Percentile }\end{array}$ & $\begin{array}{r}\text { 10th } \\
\text { Percentile }\end{array}$ & $\begin{array}{r}25 \text { th } \\
\text { Percentile }\end{array}$ & Median & $\begin{array}{r}\text { 75th } \\
\text { Percentile }\end{array}$ & $\begin{array}{r}\text { 90th } \\
\text { Percentile }\end{array}$ & $\begin{array}{r}\text { 99th } \\
\text { Percentile }\end{array}$ \\
\hline Relative Sharpe ratio loss & $3 \%$ & $0 \%$ & $1 \%$ & $1 \%$ & $1 \%$ & $1 \%$ & $5 \%$ & $66 \%$ \\
\hline Idiosyncratic risk share & $3 \%$ & $1 \%$ & $1 \%$ & $2 \%$ & $2 \%$ & $2 \%$ & $8 \%$ & $21 \%$ \\
\hline
\end{tabular}

Source: Authors’ computations. Note: N=1,003 plans.

Table 6. Determinants of Plan Menu Efficiency

\begin{tabular}{|c|c|c|c|c|}
\hline \multirow[b]{2}{*}{ Dependent variables } & \multirow[b]{2}{*}{ Mean } & $\begin{array}{c}\text { (1) } \\
\text { Plan efficiency dummy } \\
\text { (1=efficient, } 0=\text { inefficient) } \\
\text { (mean=94\%) }\end{array}$ & \multirow[t]{2}{*}{$\begin{array}{c}(2) \\
\text { Relative Sharpe } \\
\text { ratio loss } \\
(\text { mean=3\%) } \\
\text { OLS coefficient }\end{array}$} & \multirow[t]{2}{*}{$\begin{array}{c}\text { (3) } \\
\begin{array}{c}\text { Idiosyncratic } \\
\text { risk share } \\
(\text { mean=3\%) }\end{array} \\
\text { OLS coefficient }\end{array}$} \\
\hline & & Marginal effect & & \\
\hline \multicolumn{5}{|l|}{ Plan components } \\
\hline Number of funds & 12 & $-0.18 \%$ & $-0.004 * * *$ & $-0.003 * *$ \\
\hline Number of funds squared & 177 & $0.002 \%$ & $0.0001 * * *$ & $0.0001 * *=$ \\
\hline \multicolumn{5}{|l|}{ Funds offered (yes = 1) } \\
\hline Balanced index funds & 0.13 & $-3.68 \% *$ & 0.004 & -0.001 \\
\hline Balanced actively managed funds & 0.93 & $0.89 \%$ & 0.01 & $0.01 * *$ \\
\hline Bond index funds & 0.81 & $8.00 \% * * *$ & $-0.13 * * *$ & $-0.08 * *=$ \\
\hline Bond actively managed funds & 0.46 & $0.22 \%$ & $-0.05 * * *$ & $-0.01 * *$ \\
\hline Domestic equity index funds & 0.99 & $16.89 \% * *$ & 0.01 & 0.01 \\
\hline Domestic equity actively managed funds & 0.97 & $-2.30 \%$ & 0.00 & 0.01 \\
\hline International equity index funds & 0.24 & $0.69 \%$ & $0.02 * *$ & 0.01 \\
\hline International equity actively managed funds & 0.84 & $-1.88 \%$ & 0.005 & $0.01 * *$ \\
\hline Company stock & 0.11 & $-2.77 \%$ & 0.02 & $0.01 *$ \\
\hline R-squared & & 0.0426 & 0.3035 & 0.4769 \\
\hline
\end{tabular}

Source: Authors' computations. Note: Control variables at plan level include: log plan assets, log number of participants in the plan, average participant age, gender, plan tenure, log income, log non-retirement wealth, house ownership, web access, and contribution source. $\mathrm{N}=1,003$ plans. 
Table 7. Determinants of Participant Portfolio Efficiency

\begin{tabular}{|c|c|c|c|}
\hline \multirow[b]{2}{*}{ Dependent variables } & \multirow{2}{*}{ Mean } & $\begin{array}{r}\text { Relative return } \\
\text { loss (in \% per month) } \\
\text { (mean }=0.079 \%)\end{array}$ & \multirow[t]{2}{*}{$\begin{array}{c}\begin{array}{c}\text { Idiosyncratic } \\
\text { risk share (in \%) } \\
(\text { mean }=18.7 \%)\end{array} \\
\text { Coefficient }\end{array}$} \\
\hline & & Coefficient & \\
\hline \multicolumn{4}{|l|}{ Investment pattern } \\
\hline Number of funds chosen & 3.72 & $0.0005 \% * *$ & $-1.26 \% * * *$ \\
\hline Balanced index funds share & $0.5 \%$ & $-0.000001 \%$ & $0.02 \% * * *$ \\
\hline Balanced actively managed funds share & $17.8 \%$ & $-0.0002 \% * *$ & $0.16 \% * * *$ \\
\hline Bond index funds share & $5.2 \%$ & $-0.0008 \% * *$ & $0.11 \% * * *$ \\
\hline Bond actively managed funds share & $2.6 \%$ & $-0.0008 \% * *$ & $0.17 \% * * *$ \\
\hline Domestic equity actively managed funds share & $26.6 \%$ & $-0.00004 \% * *$ & $0.17 \% * * *$ \\
\hline International equity index funds share & $0.5 \%$ & $-0.0003 \% * *$ & $0.12 \% * * *$ \\
\hline International equity actively managed funds share & $3.4 \%$ & $0.0002 \% * *$ & $0.05 \% * * *$ \\
\hline Company stock share & $9.3 \%$ & $-0.0002 \% * *$ & $0.88 \% * * *$ \\
\hline \multicolumn{4}{|l|}{ (Reference: Domestic equity index funds share) } \\
\hline \multicolumn{4}{|l|}{ Participant characteristics } \\
\hline Age & 44.6 & $0.0001 \% * *$ & $0.01 \% * * *$ \\
\hline Web access (1=Yes) & 0.4 & $-0.0018 \% * *$ & $0.15 \% * * *$ \\
\hline Ln household income (\$000) & 11.2 & $-0.0001 \% *$ & $0.07 \% * * *$ \\
\hline Ln non-retirement financial wealth $(\$ 000)$ & 8.1 & $-0.0001 \% * *$ & $-0.04 \% * * *$ \\
\hline R squared & & 0.2885 & 0.6058 \\
\hline
\end{tabular}

Source: Authors' computations. Note: $\mathrm{N}=986,614$ participants. 
Figure 1. Percentage of Plans Offering Various Numbers of Funds

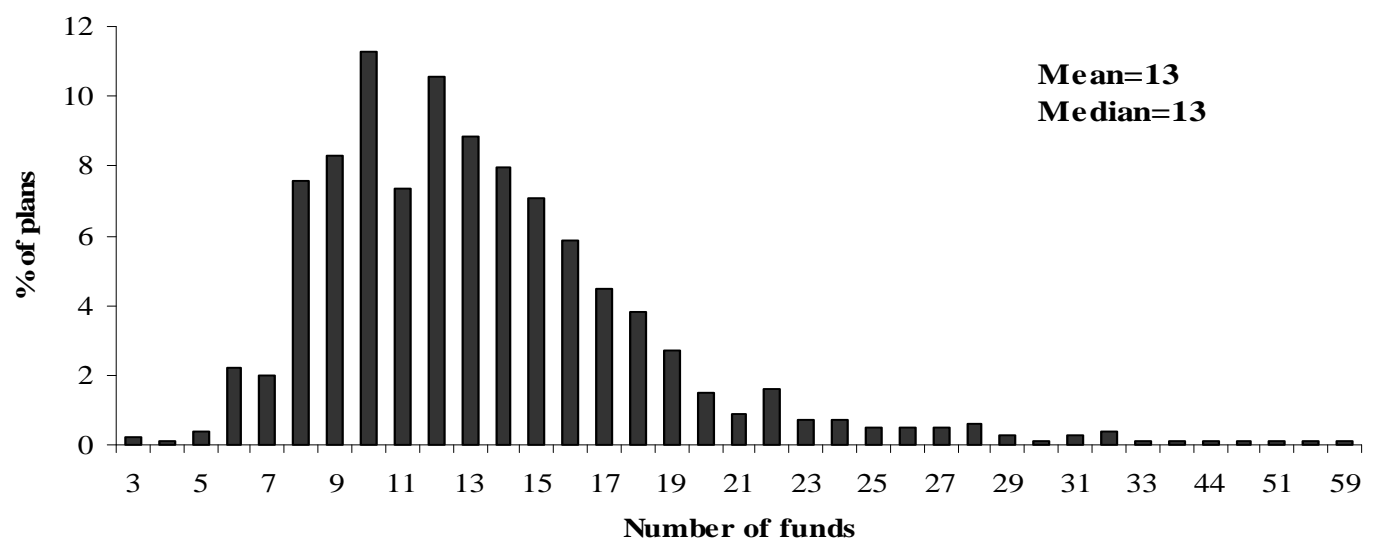

Source: Authors' computations. Note: N=1,003 plans 


\section{Figure 2. Number of Index/ Actively Managed Funds vs. Total Number of Funds}

A. Number of Index Funds by Type vs. Number of Funds Offered

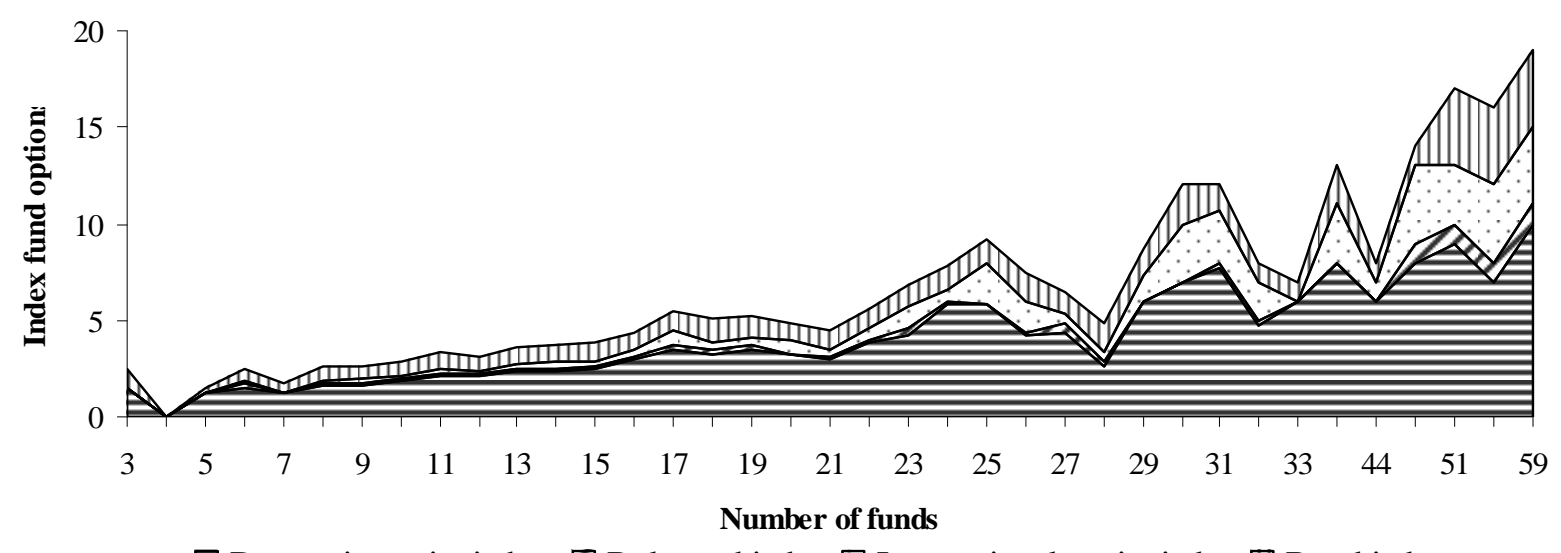

$\boxminus$ Domestic equity index $\square$ Balanced index $\square$ International equity index $\square$ Bond index

B. Number of Actively Managed (AM) Funds by Type vs. Number of Funds Offered

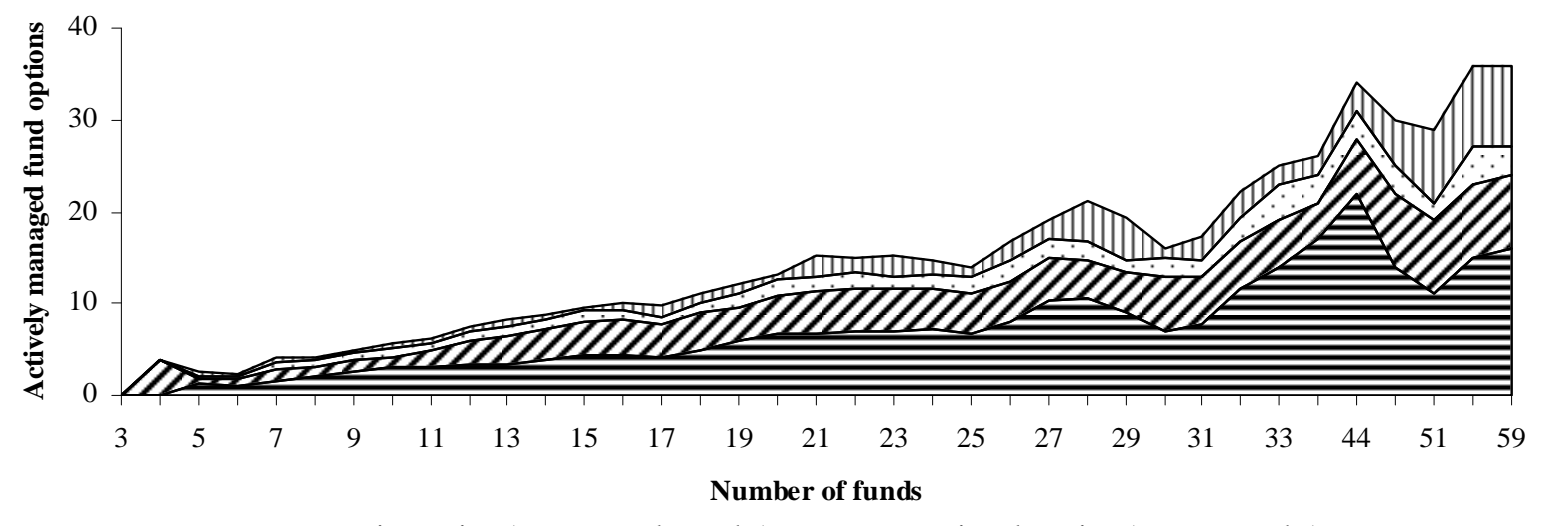

$\boxminus$ Domestic equity AM Balanced AM $\square$ International equity AM $\square$ Bond AM

Source: Authors' computations. Note: N = 1,003 plans 


\section{Figure 3. Allocation of Individual Participant Portfolios}

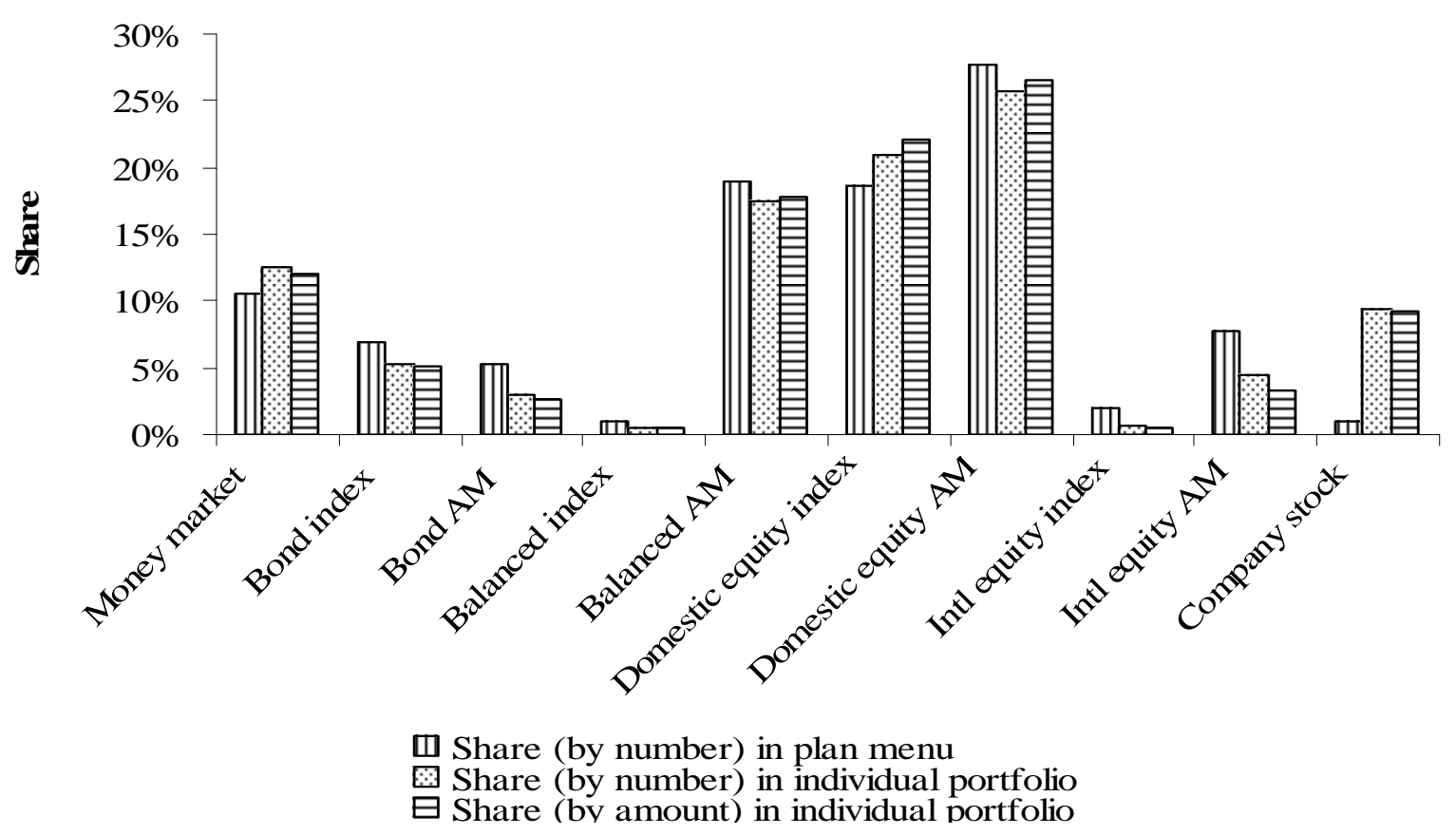

Source: Authors' computations. Note: N = 1,003 plans and 986,614 participants.

Figure 4. Illustration of Total and Relative Return Loss

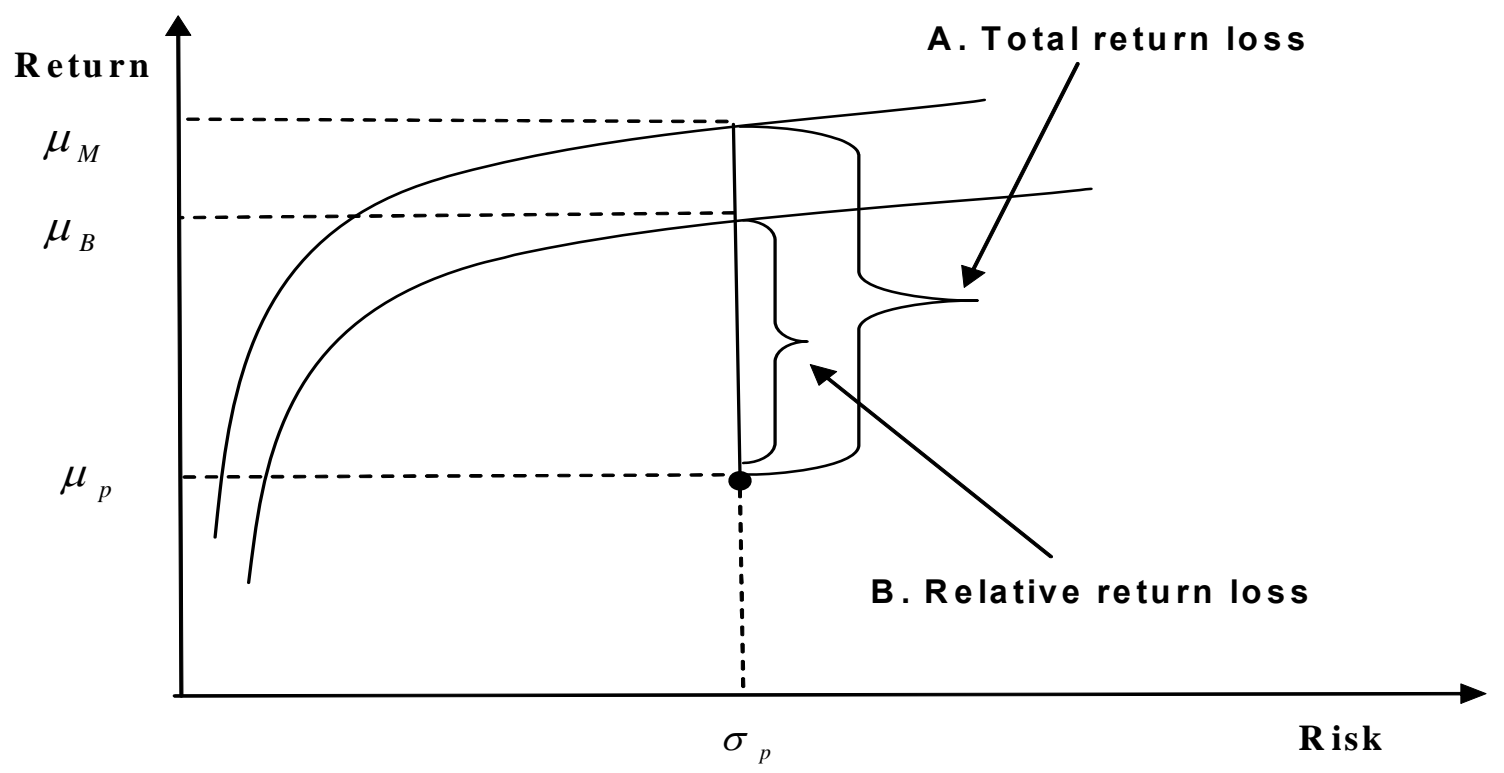


Figure 5. Distribution of Individual Portfolio Total Return and Relative Return Loss

A. Total Return Loss

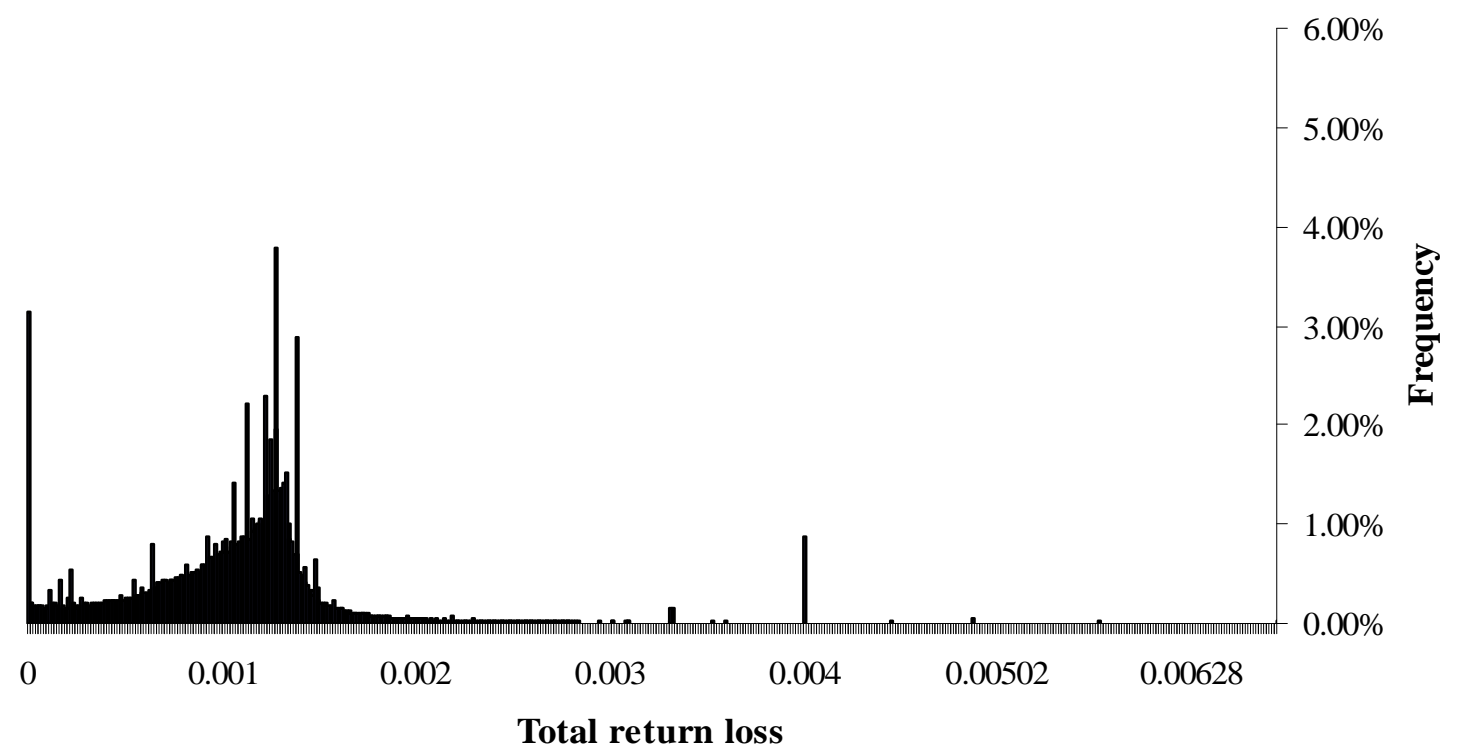

B. Relative Return Loss

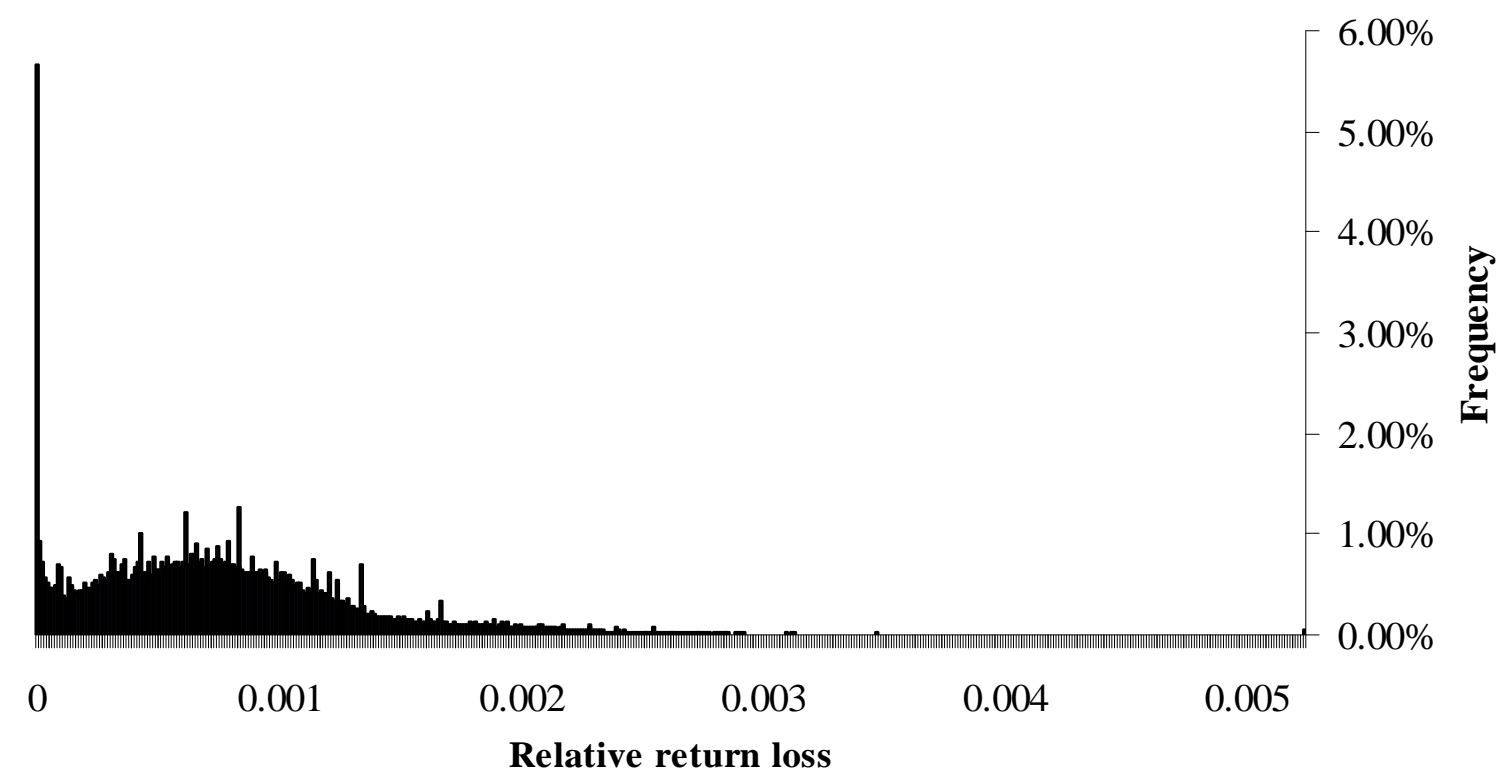

Source: Authors’ computations. Note: N = 986,949 participants. 
Figure 6. Distribution of Individual Portfolio Idiosyncratic Risk Share

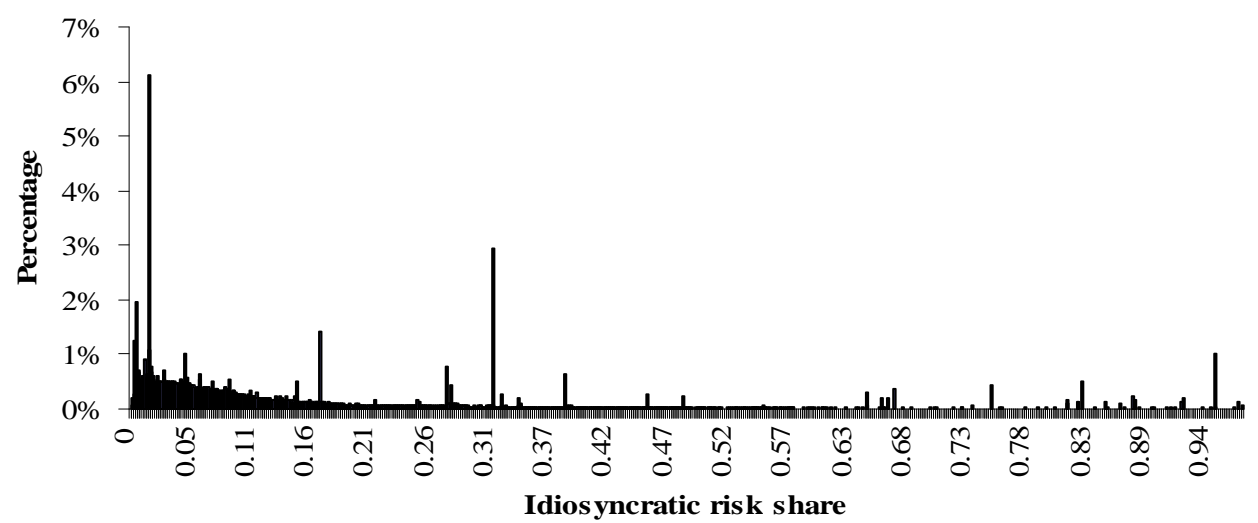

Source: Authors' computations. Note: N = 986,949 participants.

Figure 7. Actual vs. Naive Allocation Portfolio Performance

A. Monthly Relative Return Loss

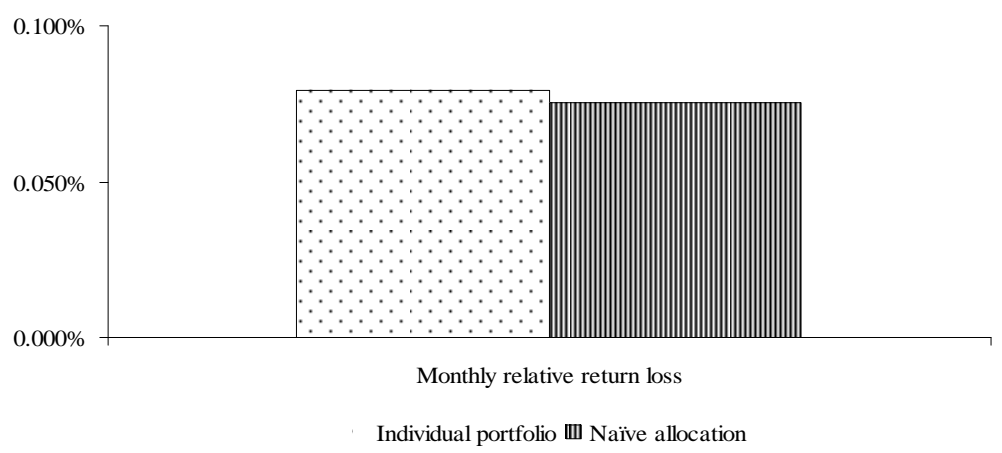

B. Idiosyncratic Risk Share

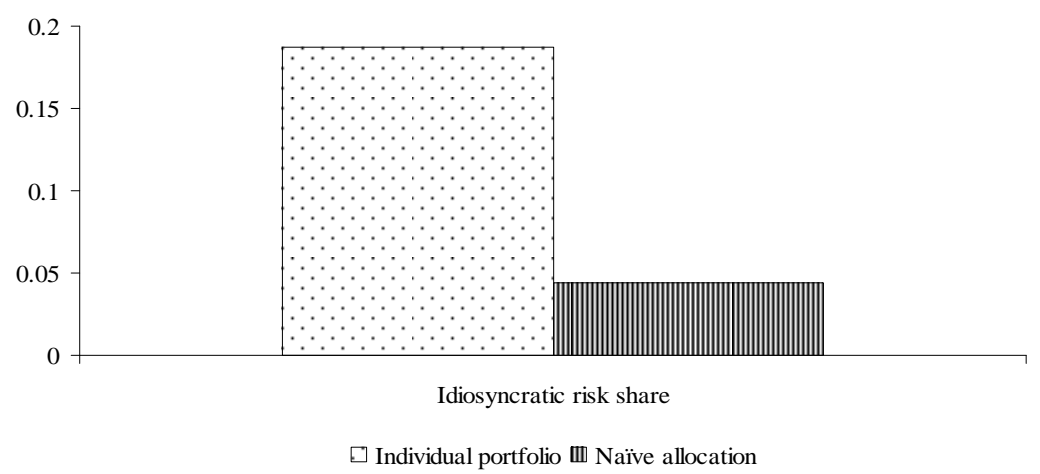

Source: Authors' computations. Note: $\mathrm{N}=986,949$ participants and 1,003 plans. 
Figure 8. Performance Measures by Menu Number of Funds Offered

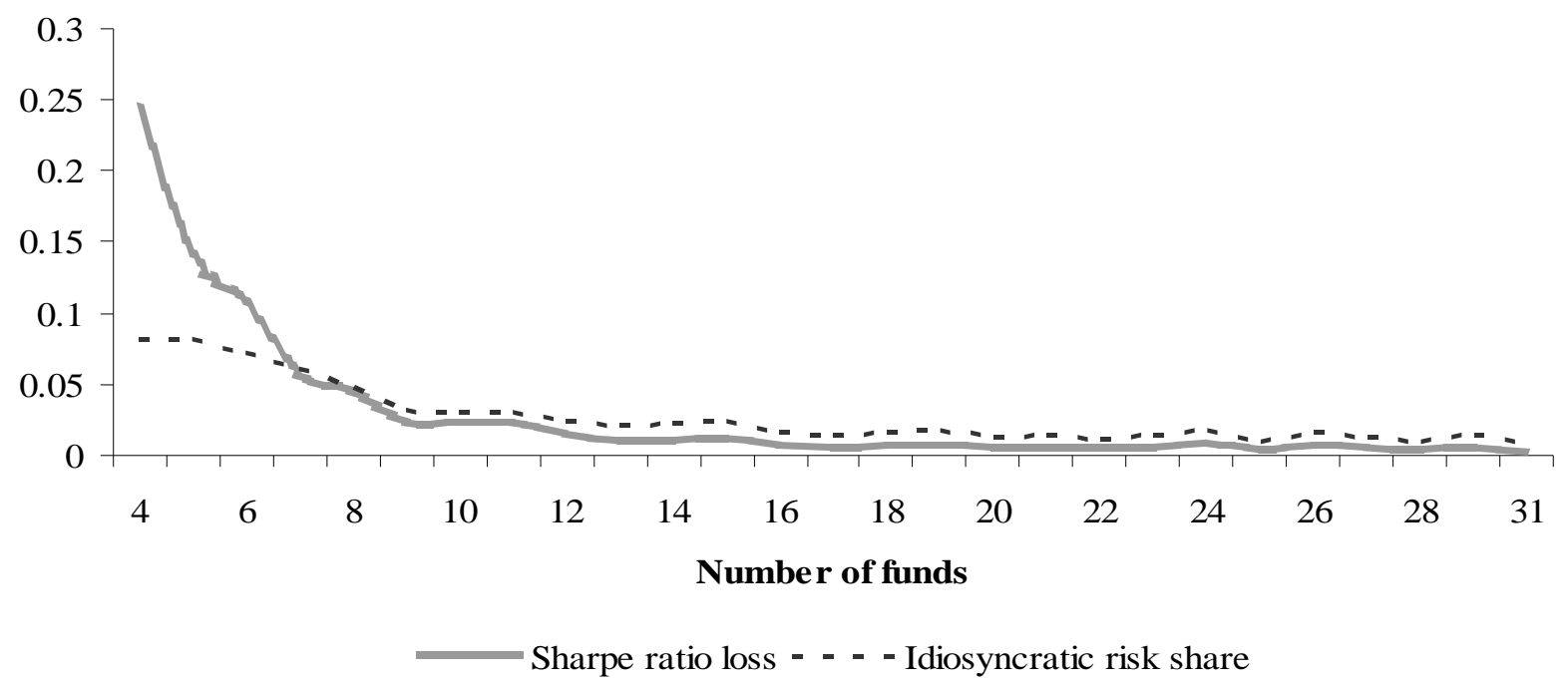

Source: Authors' computations. Note: $\mathrm{N}=993$ plans. 


\section{Appendix: Estimating Return Moments}

To compute each plan's performance measures, we must estimate each plan-specific mean and variance of returns. We adopt the CAPM asset pricing model and following Calvet, Campbell, and Sodini (2007), regress fund returns on three market indexes:

$$
R_{i t}=\beta_{i}^{1} M K T_{t}+\beta_{i}^{2} B O N D_{t}+\beta_{i}^{3} E A F E_{t}+\varepsilon_{i, t},
$$

where $R_{i, t}$ is the excess return for fund $i$; MKT is the excess return for Russell 3000 (broad domestic equity market); BOND is the excess return for Lehman US aggregate (broad domestic bond market); EAFE is the excess return for MSCI EAFE (international equity market); and the time period is 12/97 12/04 (or less if not available for some funds). Using the estimated risk loading $\hat{\beta}_{i}^{1}, \hat{\beta}_{i}^{2}, \hat{\beta}_{i}^{3}$ from the regression above, we can estimate moments for each fund: $\hat{\mu}_{f}=\hat{\beta} \hat{\mu}, \quad \hat{\Sigma}_{f}=\hat{\beta} \hat{\Sigma} \hat{\beta}^{\prime}+\hat{\Sigma}_{\text {idio }}$, where $\hat{\mu}_{f}$ is the vector of estimated mean excess return over all funds; $\hat{\Sigma}_{f}$ is the estimated variance-covariance matrix of excess returns over all funds; $\hat{\beta}$ is the vector of three betas over all funds $\hat{\beta}=\left(\hat{b}_{1}, \ldots, \hat{b}_{i}\right)^{\prime}, \hat{b}_{i}=\left(\hat{\beta}_{i}^{1}, \hat{\beta}_{i}^{2}, \hat{\beta}_{i}^{3}\right) ; \hat{\mu}$ is the mean excess return over three benchmark funds, $\hat{\mu}=\left(\hat{\mu}_{M K T}, \hat{\mu}_{\text {BOND }}, \hat{\mu}_{\text {EAFE }}\right)^{\prime} ; \hat{\Sigma}$ is the variance-covariance matrix of three benchmark funds; and $\hat{\Sigma}_{\text {idio }}$ is the estimated idiosyncratic risk of funds estimated from the variance-covariance matrix of regression residuals $\varepsilon_{i, t}$.

Based on the estimated mean and variance of returns over all funds, we estimate moments of plans: $\hat{\mu}_{p}=\omega^{\prime} \hat{\mu}_{f}, \hat{\Sigma}_{p}=\omega^{\prime} \hat{\Sigma}_{f} \omega, \hat{\Sigma}_{\text {idio, } p}=\omega^{\prime} \hat{\Sigma}_{\text {idio }} \omega$, where $\omega$ is the weight vector over all funds in each plan. 